disabled by convulsive disorder. SRS Report No. 19 p 58113 F-01. Christian Medical College and Hospital, Vellore 1971

30. Nandi DN, Ajmany $\mathrm{S}$, Ganguli $\mathrm{H}$ et al. Psychiatric disorders in a rural community in West Bengal. An epidemiological study. Indian J Psychiat 1976; 17 : 87-99

31. Aicardi J (Technical committee of the French league against epilepsy). General conclusions concerning familial factors in epilepsy. Epilepsia $1969 ; 10: 65$

32. Metrakos JD and Metrakos K. Genetic studies in clinical epilepsy. In : Basic mechanisms of epilepsies. HH Jasper, AA Ward A Pope, eds. London : J \& A Churchill Ltd.

33. Frantzen E, Lennox-Buchthal $M$, Nygaard $A$ and Stene J. A genetic study of febrile convulsions. Neurology (Minneapolis) 1970; $20: 909$

34. Ounsted C. Some aspects of seizure disorders. In : Recent advances in pediatrics. D Gairdner and D Hull, eds. London : Heinemann, 1971. $3 \mathrm{p}$
35. Malzberg B. The incidence and prevalence of intramural epilepsy. In : Epilepsy psychiatric aspects of convulsive disorders. PH Joch and RP Knight, eds. New York : Hafner; p 43

36. Reid. People with epilepsy. Report of central health services council. London : HMSO.

37. Myrianthopoulos NC. Congenital malformations : The contribution of twin studies. Birth Defects 1978; $14: 151-165$

38. Windham GC, Sever LE. Neural tube defects among twin birtbs. Amer J Hum Genet 1982; $34: 988-998$

39. Hay $S$ and Wehrung DA. Congenital malformations in twins. Amer $\mathbf{J}$ Hum Genet $1970 ; 22: 662-678$

40. Lady PM, Erickson JD, Falek A, McCarthy /BJ. Congenital malformations in twins. Amer J Hum Genet 1980; 32 : : 69-78

41. Windham GC and Bjerkedal T. Malformations in twins and their siblings, Norway, 1967-79. Twin Research 4-Part A : Biology and obstetrics. Acta Genet Med Gemellnl 1984; 33 : $87-95$

\title{
DO SEIZURES IN CHILDREN CAUSE INTELLECTUAL DETERIORATION
}

We studied whether the occurrence of seizures in childhood affected intellectual performance. We compared the full scale IQs at seven years of age of children who had experienced one or more nonfebrile seizures with the IQs of their seizurefree siblings who where tested at the same age in a large longuitudinal study. Among 98 children with seizures, the mean score on IQ tests at seven years was not signjficantly different from the mean score of their siblings. Mental retardation was more common among the children with seizures, but the excess was accounted for by children who had neurologic abnormalities before the first sizures. We also examined the IQ before and after the onset of seizures in 62 children whose first seizure occurred in the interval between psychometric examinations given at four and seven years of age. The IQ at seven years in the children with seizures did not differ significantly from that in controls matched for IQ (as determined at the four-year assessment), sex race, and socioeconomic status. Thus in both the sibling-control comparison and the comparisons made between controls and subjects before and after the onset of seizures, the occurence of nonfebrile seizures was not associated with a significant change in full-scale IQ. 